IZA DP No. 4477

Spillovers Through Backward Linkages from Multinationals: Measurement Matters!

Salvador Barrios

Holger Görg

Eric Strobl

October 2009 


\title{
Spillovers Through Backward Linkages from Multinationals: Measurement Matters!
}

\author{
Salvador Barrios \\ Institute for Prospective Technological Studies - IPTS \\ European Commission, Sevilla
}

Holger Görg

Kiel Institute for World Economy,

University of Kiel and IZA

Eric Strobl

Ecole Polytechnique Paris

and IZA

Discussion Paper No. 4477

October 2009

\author{
IZA \\ P.O. Box 7240 \\ 53072 Bonn \\ Germany \\ Phone: $+49-228-3894-0$ \\ Fax: +49-228-3894-180 \\ E-mail: iza@iza.org
}

\begin{abstract}
Any opinions expressed here are those of the author(s) and not those of IZA. Research published in this series may include views on policy, but the institute itself takes no institutional policy positions.

The Institute for the Study of Labor (IZA) in Bonn is a local and virtual international research center and a place of communication between science, politics and business. IZA is an independent nonprofit organization supported by Deutsche Post Foundation. The center is associated with the University of Bonn and offers a stimulating research environment through its international network, workshops and conferences, data service, project support, research visits and doctoral program. IZA engages in (i) original and internationally competitive research in all fields of labor economics, (ii) development of policy concepts, and (iii) dissemination of research results and concepts to the interested public.
\end{abstract}

IZA Discussion Papers often represent preliminary work and are circulated to encourage discussion. Citation of such a paper should account for its provisional character. A revised version may be available directly from the author. 


\section{ABSTRACT \\ Spillovers Through Backward Linkages from Multinationals: Measurement Matters!*}

We argue that the measures of backward linkages used in recent papers on spillovers from multinational companies are potentially problematic, as they depend on a number of restrictive assumptions, namely that (i) multinationals use domestically produced inputs in the same proportion as imported inputs, (ii) multinationals have the same input sourcing behaviour as domestic firms, irrespective of their country of origin, and (iii) the demand for locally produced inputs by multinationals is proportional to their share of locally produced output. We discuss why these assumptions are likely to be violated in practice, and provide alternative measures that overcome these drawbacks. Our results, using plant level data for Ireland, show clearly that the choice of backward linkage measure and thus, the assumptions behind them, matters greatly in order to draw possible conclusions regarding the existence of FDI-related spillovers. Using the standard measure employed in the literature we fail to find robust evidence for spillovers through backward linkages. However, when we use alternative measures of backward linkages that relax assumptions (i)-(iii), we find robust evidence for positive FDI backward spillover effects.

JEL Classification: F23, L22

Keywords: multinationals, backward spillovers, productivity spillovers

Corresponding author:

Holger Görg

University of Kiel

Institut für Volkswirtschaftslehre

Wilhelm-Seelig-Platz 1

24118 Kiel

Germany

E-mail: goerg@economics.uni-kiel.de

\footnotetext{
* The authors are grateful to Beata Javorcik, Wolfgang Keller, Bob Lipsey, Selin Sayek, Fredrik Sjöholm and seminar participants at Bilkent, Kiel, Nijmegen and the ETSG meeting at Rome for very helpful comments on earlier drafts. The views expressed by the authors are not necessarily those of the institutions they are affiliated with. Any errors remain the authors' alone.
} 


\section{Introduction}

While the first paper on productivity spillovers to host country firms from multinational companies (MNCs) was published more than thirty years ago (Caves, 1974), the search for these effects is still going strongly. ${ }^{2}$ This reflects not only the considerable policy interest into whether or not there are such productivity benefits for local firms from inward foreign direct investment (FDI), but also the fact that results for the most part have not been very conclusive. Importantly, much of the literature has (with limited success) searched only for horizontal spillovers, i.e., benefits to domestic firms operating in the same industry as the MNCs. However, several theoretical contributions showed that spillovers through backward linkages, i.e., benefits to domestic firms that operate in sectors that supply inputs to multinationals, could be another important channel; see for instance Rodriguez-Claré (1996) and Markusen and Venables (1999). Additionally, a number of anecdotes and case studies also suggested that many multinationals play an important role in actively assisting their suppliers in host countries to improve their quality and efficiency (e.g., Moran, 2001). Indeed, several recent empirical studies using large firm level data sets seem to have now confirmed the importance of such positive vertical spillover effects (e.g., Javorcik, 2004; Gorodnichenko, 2007, Blalock and Gertler, 2008) providing, seemingly, an answer as to why much of the literature on horizontal spillovers failed to find a beneficial role of multinationals in the host economy.

Of course, the reliability of evidence in support of the existence of spillovers, whether of a horizontal or vertical nature, depends crucially on the plausibility of their proxies employed. The empirical strategy in capturing the importance of backward linkage spillovers has essentially exclusively consisted of using the share of foreign multinational output in each

\footnotetext{
${ }^{2}$ There is a large and still growing literature on this. Recent published papers include Javorcik and Spatareanu (2008), Girma and Wakelin (2009), Keller and Yeaple (2009). Görg and Strobl (2001) and Keller (2004) provide comprehensive overviews of this literature.
} 
sector as a measure of their total demand of inputs in that sector, and input-output tables of the host country to proxy how this demand was distributed across sectors. Importantly, however, measuring backward linkages in such a way relies on a number of underlying assumptions about the nature of input demand of foreign multinationals. In a nutshell, these are that (i) multinationals use domestically produced inputs in the same proportion as imported inputs, (ii) that foreign firms have the same input sourcing behaviour as domestic firms, and all MNCs have the same inputs sourcing behaviour irrespective of their origin, and (iii) that multinationals' demand for locally produced inputs is proportional to the share of output produced by MNCs in a given sector.

In this paper we explicitly address the plausibility of these assumptions - an aspect previously neglected in the literature. More precisely, we clearly spell out the assumptions, discuss why these are likely to be violated in practice, and provide alternatives that attempt to at least partly overcome these limitations. We then illustrate the importance of using the alternative proxies of backward linkages with manufacturing plant level data for the Republic of Ireland. This case-study is particularly relevant as FDI in Ireland is well known to have played an important role for economic growth over the last three decades. We focus on FDI in manufacturing sectors as these are in general more prone to benefit local producers via backward linkages compared to other sectors of activity, see in particular the seminal contribution by Hirschman (1958).

Our results show clearly that the choice of backward linkage measure matters greatly to determine whether or not FDI is beneficial to the host economy. For instance, using the standard measure employed in the literature we fail to find any robust evidence for spillovers through backward linkages. In contrast, measures of backward linkages relaxing assumptions (i)-(iii) produce positive backward spillover effects. Importantly, this result is robust to 
controlling for any potential endogeneity of the spillover variable related to the fact that multinationals may be more prevalent in sectors of activity with potentially higher backward spillovers. In order to tackle the endogeneity issue we use instrumental variables techniques. To generate a valid and relevant instrument, we exploit unique firm level data related to a particular feature of Irish industrial policy, namely, its explicit financial support to multinationals which is, inter alia, aimed at promoting linkages and ultimately spillovers to the domestic economy. As an alternative, we also use a System GMM approach which uses suitably lagged levels and differences of the endogenous variables as instruments.

We also show that our preferred measure of backward linkages, which uses the inputoutput table for the home country of multinationals rather than the host country, produces results that are unlikely to be generated by chance. To show this we compare our results to that of hypothetical linkages based on randomly assigned input-output coefficients. Hence, we conduct a Monte Carlo experiment where we assign randomly chosen IO coefficients to firm nationalities, and repeat this experiment 500 times. We show that the results we get using our preferred measure of backward linkages (but not that obtained using the standard measure!) differ from this hypothetical pattern, which we take to indicate that our approach provides useful information and does not just reflect a random process.

The remainder of the paper is structured as follows. Section 2 discusses the proxies for horizontal and backward spillovers used in the literature, and identifies the assumptions and their drawbacks implicit in the latter and proposes alternatives that overcome these arguably unrealistic assumptions. Section 3 describes the plant level data used in the econometric analysis, which is described in Section 4. Section 5 presents some conclusions.

\section{Proxies of horizontal and vertical spillovers}


As noted earlier, traditionally the literature estimating spillovers from FDI has focused on horizontal, i.e., within industry, spillovers, and only recently turned its attention to spillovers due to vertical linkages, related to the input-output structure of the economy. More precisely, the standard measure used to proxy horizontal spillovers is:

$\operatorname{HORIZONTAL}_{j t}=Y_{j t}^{f} / Y_{j t}$

where the numerator is the total production of foreign affiliates $f$ in industry $j$ at time $t$ and the denominator is total output (i.e., output of foreign and domestic plants) of the same industry in the same year. In other words, this index represents the proportion of the total output of a given industry in a given year produced by all foreign affiliates. As a measure of foreign presence in the industry this variable was used in the initial spillover study (Caves, 1974) and in many papers since.

The measurement of backward linkages was brought to the fore by Javorcik (2004). The main idea is to calculate a variable which captures the effect that the greater the proportion of output supplied by domestic firm $i$ to foreign affiliates, the higher the potential spillovers through backward linkages. To measure this Javorcik (2004) used the following proxy:

$$
\text { BACKWARD_IO }{ }_{j t}=\sum_{k} \alpha_{k j}^{I O} \text {HORIZONTAL }_{k t} \quad \text { for } k \neq j
$$

where HORIZONTAL $L_{k t}$ is defined as above. $\alpha_{k j}^{I O}$ is the proportion of the output of sector $j$ supplied to industry $k$, i.e. $\alpha_{k j}=Y_{k j} / Y_{k}$, such that $Y_{k j}$ is industry $j$ 's output provided to industry $k .^{3}$ To approximate $\alpha_{k j}^{I O}$ the approach by Javorcik (2004) and subsequent papers thus far has been to use the input-output coefficients from the host country's input-output (I-O) tables.

\footnotetext{
${ }^{3}$ One may want to note that these coefficients are generally from a single year since I-O tables tend to be available only over long time intervals. This, however, may not be too much of a problem as input-output relationships only change slowly over time. Our data similarly also only provides us with I-O coefficients for one year.
} 
These coefficients are calculated excluding products supplied for final consumption but including imports of intermediate goods.

Importantly, it needs to be made clear that defining HORIZONTAL and the $\alpha_{k j}^{I O}$ 's in such a measure of backward linkages implicitly assume the following conditions to hold:

A1: Domestically produced inputs are used in the same proportion as imported inputs.

A2: Foreign multinationals have the same input sourcing behaviour as domestic firms, and multinationals from different nationalities have the same input sourcing behaviour.

A3: The share of total output by foreign multinationals in a sector is reflective of their demand for locally produced inputs.

$A 1$ and $A 2$ follow directly from using input demand coefficients for intermediate products from total I-0 tables of the host country, while $A 3$ is a result of using HORIZONTAL as a proxy for input demand of foreign multinationals within a sector.

However, it can be easily argued that these assumptions are in reality likely to be violated. For example, with regard to $A 1$ the recent literature on international outsourcing of intermediate inputs suggests that firms are likely to outsource different stages of production abroad, and hence import different types of inputs, than they source in the domestic economy, even within standard industry classifications. ${ }^{4}$

It is also unlikely that foreign multinationals have the same input sourcing behaviour as domestic firms, as suggested by $A 2$. Importantly in this regard one should note that the same input sourcing behaviour would implicitly mean that foreign multinationals have the same production technology as indigenous operations. This would appear, however, to lie in

\footnotetext{
${ }^{4}$ For example, the studies by Görg et al. (2008) and Amiti and Wei (2009) suggest that the use of internationally outsourced materials or services affects productivity differently than using domestic inputs. Also, Munch and Skagsten (2009) show that internationally outsourced and domestically sourced inputs have different effects on wages for workers, suggesting that they are different types of inputs.
} 
contradiction to the very premises behind the possibility of FDI spillovers, i.e., that foreign multinationals have superior technology and knowledge from which the host economy can learn (e.g., Markusen, 2002). Moreover, the extent of local input sourcing may differ across foreign nationalities. In this context, Rodriguez-Claré (1996) shows that the decision of whether or not to source inputs locally is likely to depend on distance, with multinationals from neighbouring countries being more likely to source inputs from home due to relatively low transport costs.

Similarly, one can also argue that assumption A3 is unlikely to hold in reality. Firstly, nothing guarantees that the proportion of locally sourced inputs to locally produced outputs is constant within and across broadly defined sectors. In other words, the underlying production technology may differ across producers of different products encapsulated in the same broad sector of activity. Additionally, similarly to one of the criticisms underlying $A 2$, the extent of local input sourcing may differ across foreign nationalities and this may not be proportional to differences in output across nationalities if their technologies and/or their tendency to import are strongly influenced by home-country specific characteristics. ${ }^{5}$

All of the criticisms stated above could arguably lead to biased measures of backward linkages and hence to biased estimates of their impact on productivity. Moreover, it is not a priori clear whether these would lead to an upward or downward bias in the estimates. The purpose of this paper is thus to explicitly investigate the extent of the potential problems in

\footnotetext{
${ }^{5}$ For instance Japanese multinationals tend to buy intermediate inputs from other Japanese multinationals (or SMEs) belonging to the same Keiretsu which in turn influence their overseas affiliates' demand for local intermediates inputs, see for instance Belderbos et al. (2001). The latter is especially true if Japanese multinationals also tend to locate in the same (or neighbouring) countries, see Head and Mayer (2004). More generally, beyond the case of Japanese companies, the business literature has provided extensive evidence showing that the sourcing policy of a multinational company is the result of the firm's decisions which is largely influenced by the firm's nationality of ownership and national networks which may translate into intense backward-forward linkages within firms and also between firms sharing the same nationality, see in particular Buckley and Pierce (1979).
} 
estimates of spillovers through backward linkages using the case study of Ireland. In particular, our data allow us to consider the following issues.

First, the Irish I-O tables, which we use here, allow the distinction between imported and domestically sourced inputs. Hence, our first alternative measure uses I-O coefficients, $\alpha_{k j}^{N I M P}$ calculated using only domestically sourced inputs:

$B A C K W A R D_{-} N I M P_{j t}=\sum_{k} \alpha_{k j}^{N I M P} H_{O R I Z O N T A L_{k t}}$ for $k \neq j$

One should note that (3) allows us to examine the validity of $A 1$, assuming that $A 2$ and $A 3$ hold. Second, we make use of input-output tables for a large number of different countries in order to calculate the $\alpha$ 's separately for multinationals from the I-O table of their own home country rather than that of the host country. The measure of backward linkages using the home-country I-O table can be defined as follows:

$B A C K W A R D_{-} H O M E_{j t}=\sum_{k} \sum_{n} \alpha_{k n j}^{H O M E} H O R I Z O N T A L_{k n t} \quad$ for $k \neq j$

where $n$ refers to the nationality origin of the foreign multinational types. This measure, hence, allows for different input-sourcing behaviour according to the home country of the multinationals, rather than constraining all foreign firms to share the same technology. It thus addresses potential problems inherent in $A 2$, assuming that $A 1$ and $A 3$ are true. ${ }^{6}$ In particular, it allows us to examine whether the assumption that foreign multinationals' input sourcing behaviour is more like that found in its origin country rather than in the host country, might alter any conclusion regarding spillovers from backward linkages.

In order to address A3 we take advantage of the fact that the Irish data also collects information on the total amount of inputs a multinational sources in the domestic economy.

\footnotetext{
${ }^{6}$ One should note that the foreign I-O tables do not allow us to purge out imported inputs. We are thus essentially assuming that $A 1$ holds but within the foreign multinationals' origin country context.
} 
Unfortunately, we do not know from which industries these inputs are purchased, and thus need to again proxy these. In order to examine $A 3$ assuming that $A 1$ and $A 2$ hold, we thus start out first using the simple I-O tables, as in the original backward linkages measure described in (2) and combine it with information on domestic inputs used by multinationals:

$$
\text { ALTERNATIVE_IO }{ }_{j t}=\sum_{k} \alpha_{k j}^{I O} \frac{\sum_{n} M_{n k t}^{D}}{\sum_{n} M_{n k t}} \quad \text { for } k \neq j
$$

where $M^{D}$ is the amount of material inputs sourced domestically by a given multinational $n$ and $M$ is the total amount of material inputs used by $n$. We also experiment by combining the same information with the measure described in (3):

$$
A L T N E R N A T I V E_{-} N I M P_{j t}=\sum_{k} \alpha_{k j}{ }^{N I M P} \frac{\sum_{n} M_{n k t}^{D}}{\sum_{n} M_{n k t}} \quad \text { for } k \neq j
$$

One should note that the measure proposed in (6) lets us investigate how jointly relaxing A1 and $A 2$, but assuming that $A 3$ still holds, affects any vertical spillover estimation. Viewed in conjunction with the results from using (3) and (5), this allows us to then at least roughly get a feel for whether the restriction inherent in $A 1$ or that in $A 2$, assuming that $A 3$ still holds, plays greater role in determining results.

Finally we propose a measure that relaxes all three assumptions. More specifically, we calculate the amount of inputs demanded by other sectors $(k)$ from sector $j$ by combining the firm specific measure of multinational's demand for locally sourced inputs and the home country’s foreign I-O table:

$$
\text { ALTERNATIVE_HOME }_{j t}=\sum_{k} \alpha_{k j}^{\text {home }} \frac{\sum_{n} M_{n k t}^{D}}{\sum_{n} M_{n k t}} \quad \text { for } k \neq j
$$


One should note that of all of our proposed alternative proxies for backward linkages, this is the least restrictive. Arguably this measure is the most preferable, as it only impose the assumption that foreign multinationals have the same sourcing behaviour as their sectoral counterparts in their origin country. This of course begs the question of whether the latter is a realistic assumption. In this regard it is important to point out that there is plenty of case-study evidence which shows that foreign affiliates implement technology in the host country that is state-of-the-art and similar to that employed in the home country parent. For instance, Moran (2001, 2005) provides examples for the automobile and, more relevant for Ireland, computer and electronics industries. Recent evidence from a unique and large firm level database of multinationals around the world by Alfaro and Charlton (2009) also shows that parents of multinationals choose to own affiliates abroad that are in stages of the production process that are very close to their own (in terms of 4 digit industry classification). If the affiliates use similar technology to the parent, then they are also likely to source inputs from different supplier industries in a way similar to the parent.

Furthermore, there are also plenty of studies on the sourcing behaviour of multinationals that show that foreign multinationals are likely to source fewer of their inputs in the host economy than comparable domestic firms do. ${ }^{7}$ More generally, this amounts to assuming that a given foreign affiliate follows the organisation mode of its parent, which would allow the latter to compete successfully with its domestic counterparts abroad. Again, this suggests that using I-O tables from foreign multinationals' origin country is likely to provide a closer approximation of foreign multinational sourcing behaviour than employing the host country's IO table.

\footnotetext{
${ }^{7}$ For Ireland, this has been documented by, e.g., Ruane (2001) and Barry and Bradley (1997).
} 
Besides horizontal and backward spillovers, Javorcik (2004) also calculate a measure of forward linkages,

FORWARD_IO ${ }_{j t}=\sum_{k} \beta_{k j}^{I O}$HORIZONTAL $_{k t} \quad$ for $k \neq j$

where $\beta_{k j}^{I O}$ is the share of inputs of sector $j$ purchased from industry $k$. Hence, this variable gives an indication of the availability of intermediate inputs supplied by foreign multinationals that are available to domestic firms in industry $j$. We calculate this measure in a similar way, but using $\beta_{k j}^{N I M P}$, i.e., excluding imports of goods in order to deal with assumption A1.

As we are now looking at domestic firms sourcing inputs from foreign multinationals, the domestic IO table can be assumed to describe adequately their sourcing behaviour, hence assumption A2 is not relevant. In terms of assumption A3 this may similarly apply to domestic firms, unfortunately, we do not have detailed data that would allow us to relax this assumption for the case of domestic firms. At any rate, given that our focus is on backward linkages, as is the case in the literature, we treat forward linkages mainly as a control variable. ${ }^{8}$

\section{Data and Summary Statistics}

The data for our empirical investigation are taken from the Irish Economy Expenditure Survey (IEE), undertaken annually over the period 1983-1998 by Forfás, the government agency with responsibility for enterprise development, science and technology. This is an annual survey of larger plants in Irish manufacturing with at least 20 employees, although a plant, once it is included, is generally still surveyed even if its employment level falls below the 20 employee cut-off point. The response rate to this survey is generally estimated to be

\footnotetext{
${ }^{8}$ In fact, if one is concerned about the backward spillovers variable than one solution may be to drop it completely, as it has been found in the literature that forward spillovers are generally statistically insignificant. We experimented re-running all of our models below excluding the forward linkages variables, this does not affect our main conclusion on the backward spillover variables.
} 
between 60 and 80 per cent of the targeted plant population. Hence, while our data can be regarded as representative of the targeted population of plants, it does not generally include plants with less than 20 employees.

The survey provides plant level information needed to calculate productivity performance including, inter alia, output (measured in terms of sales), value added (sales minus intermediate inputs), employment, wages, capital employed, and nationality of ownership. Additionally, we have details on plants' expenditure on raw materials and components (which we refer to as materials) and the proportion of these sourced abroad. ${ }^{9}$ One should note, however, that information on the capital stock is only available from 1990 onwards, and hence, since we focus on total factor productivity, our sample period consists of the years 1990-1998.

A plant is defined by Forfás as foreign owned if at least 50 percent of its shares are held by foreign owners. Note that the dataset only provides us with an indicator variable for foreign ownership, not the actual ownership share. Our selection of Irish owned plants will thus be based on plants with less than 50\% foreign ownership. While this may leave out plants with minority foreign ownership it has been the case in Ireland, certainly over the period covered, that most FDI was in the form of new wholly foreign-owned greenfield investment (see, e.g., Barry and Bradley, 1997). Hence, this should not cause a problem in our analysis.

Our plant level data is combined with the Input-Output table for Ireland and input output tables taken from the OECD database on I-O tables. Those tables are not available for the same year across all countries such that we used in each case the year that matched most

\footnotetext{
${ }^{9}$ Materials not sourced abroad may have been purchased from foreign affiliates of multinationals located in Ireland rather than just from purely domestic firms. Unfortunately, the data set does not allow us to distinguish these two sources for domestically purchased inputs. Also, the data set does not provide information on the source country or industry of the inputs.
} 
closely the period available in the Irish data for the following foreign countries (the year of the I-O being indicated in parentheses): Canada (1997), Germany (1995), Denmark (1997), Spain (1995), Finland (1995), France (1995), Greece (1994), Italy (1992), Japan (1997), Netherlands (1998), Norway (1997), United Kingdom (1998), United States (1997), Korea (2000), China (2000), India (1995), Switzerland (2001), Austria (1995), and Australia (1998). The lack of foreign input-output tables for any remaining multinationals in the IEE data meant their exclusion. Those from the countries listed above constituted in any year well over 98 per cent of total foreign output and over 97 per cent of total foreign employment located in Irish manufacturing. The share of total foreign output by nationality group is given in Table 1 .

Table 1: Share of output by nationality of foreign owner

\begin{tabular}{|l|l|l|l|}
\hline Nationality & Code & Share(\%) & Input $_{\text {local }} /$ Input $_{\text {total }}$ \\
\hline Canada & CA & 2.6 & 0.23 \\
\hline Germany & DE & 6.0 & 0.20 \\
\hline Denmark & DK & 0.6 & 0.25 \\
\hline Spain & ES & 0.1 & 0.38 \\
\hline Finland & FI & 0.3 & 0.25 \\
\hline France & FR & 3.4 & 0.27 \\
\hline Greece & GR & 0.2 & 0.98 \\
\hline Italy & IT & 1.0 & 0.26 \\
\hline Japan & JP & 5.6 & 0.15 \\
\hline Netherlands & NL & 2.5 & 0.31 \\
\hline Norway & NO & 0.1 & 0.22 \\
\hline United Kingdom & UK & 12.9 & 0.25 \\
\hline United States & US & 61.8 & 0.27 \\
\hline Korea & KO & 0.1 & 0.71 \\
\hline China & CH & 0.1 & 0.66 \\
\hline India & IN & 0.1 & 0.33 \\
\hline Switzerland & SZ & 1.7 & 0.32 \\
\hline Australia & AU & 0.5 & 0.36 \\
\hline Austria & AT & 0.1 & 0.37 \\
\hline
\end{tabular}

Sources: Irish Economy Expenditure Survey, Forfás and authors' calculations

In choosing an industry classification we settled on the one that allowed us to combine all data sets, roughly equivalent to the ISIC Rev.3 classification at the two digit level. This left us with a total of 19 sectors, which are listed in Table 2. All nominal variables are deflated 
using Irish sectoral prices from the EU KLEMS database. ${ }^{10}$ Overall our econometric analysis allows the estimation of productivity determinants for 1,037 domestic Irish-owned plants over our sample period.

To first investigate whether the use of imported inputs versus locally produced ones differs, we calculated the correlation of the $\alpha$ 's for imported and locally produced inputs (i.e., $\alpha_{k j}^{N I M P}$ and $\alpha_{k j}^{I O}$ ) within our 19 sectors in the third column of Table 2. In this regard it is important to note that for three of these sectors we were not able to calculate out correlation coefficients since no inputs were imported. Of those where at least some inputs were imported, the results of Table 2 suggest that there is little evidence that the sectoral structure of locally sourced inputs is correlated with that of imported inputs.

Table 2: Correlations of I-O tables

\begin{tabular}{|c|c|c|c|}
\hline Sector & Sector \# & Corr. of I-O’s & $\begin{array}{l}\operatorname{Corr}\left(\mathrm{M}^{\mathrm{D}}{ }_{\mathrm{nkt}} / \mathrm{M}_{\mathrm{nkt}},\right. \\
\left.\mathrm{Y}_{\mathrm{jt}}^{\mathrm{F}} / \mathrm{Y}_{\mathrm{jt}}\right)\end{array}$ \\
\hline Mining \& Quarrying & 1 & -0.18 & 0.10 \\
\hline Food, Beverages, \& Tobacco & 2 & -0.23 & -0.26 \\
\hline Textiles, Clothing, \& Leather & 3 & -0.06 & -0.22 \\
\hline Wood \& Wood Products & 4 & -0.02 & 0.74 \\
\hline Paper \& Printing & 5 & -0.04 & -0.63 \\
\hline Coke \& Petroleum Pr. & 6 & --- & 0.99 \\
\hline Chemicals & 7 & 0.29 & 0.54 \\
\hline Rubber \& Plastics & 8 & --- & -0.39 \\
\hline Other Non-Metallic Minerals & 9 & 0.67 & 0.54 \\
\hline Basic Metals & 10 & 0.41 & 0.63 \\
\hline Fabricated Metals & 11 & --- & -0.77 \\
\hline Machinery \& Equipment & 12 & -0.12 & 0.28 \\
\hline Office \& Computing Machinery & 13 & 0.11 & -0.89 \\
\hline Electrical \& Electronic & 14 & 0.16 & 0.17 \\
\hline Radio, Television, \& Communica & 15 & 0.14 & -0.09 \\
\hline Medical, Precision, \& Optical & 16 & -0.19 & -0.65 \\
\hline Motor Vehicles & 17 & -0.19 & 0.05 \\
\hline Other Transport Equipment & 18 & 0.02 & 0.32 \\
\hline Other & 19 & --- & 0.52 \\
\hline
\end{tabular}

Sources: Irish Economy Expenditure Survey, Forfás and authors' calculations

\footnotetext{
${ }^{10}$ The database is available at www.euklems.net
} 
We also calculated the correlation of the I-O coefficients from the Irish I-O (total) with their foreign equivalents for each sector, as depicted in Figure 1. Accordingly, in some sectors, namely Food, Beverages, \& Tobacco, Textiles, Clothing, \& Leather, Wood \& Wood Products, and Paper \& Printing (i.e. sectors 2 to 5 in Table 2) the assumption that the local I-O tables serve as good proxies for foreign multinational input use appears to be a reasonable assumption as the correlation for most nationalities with the Irish coefficients is close to 1 . However, it is clear that for the majority of industries this is not the case.

Figure 1: Correlations by sector and country

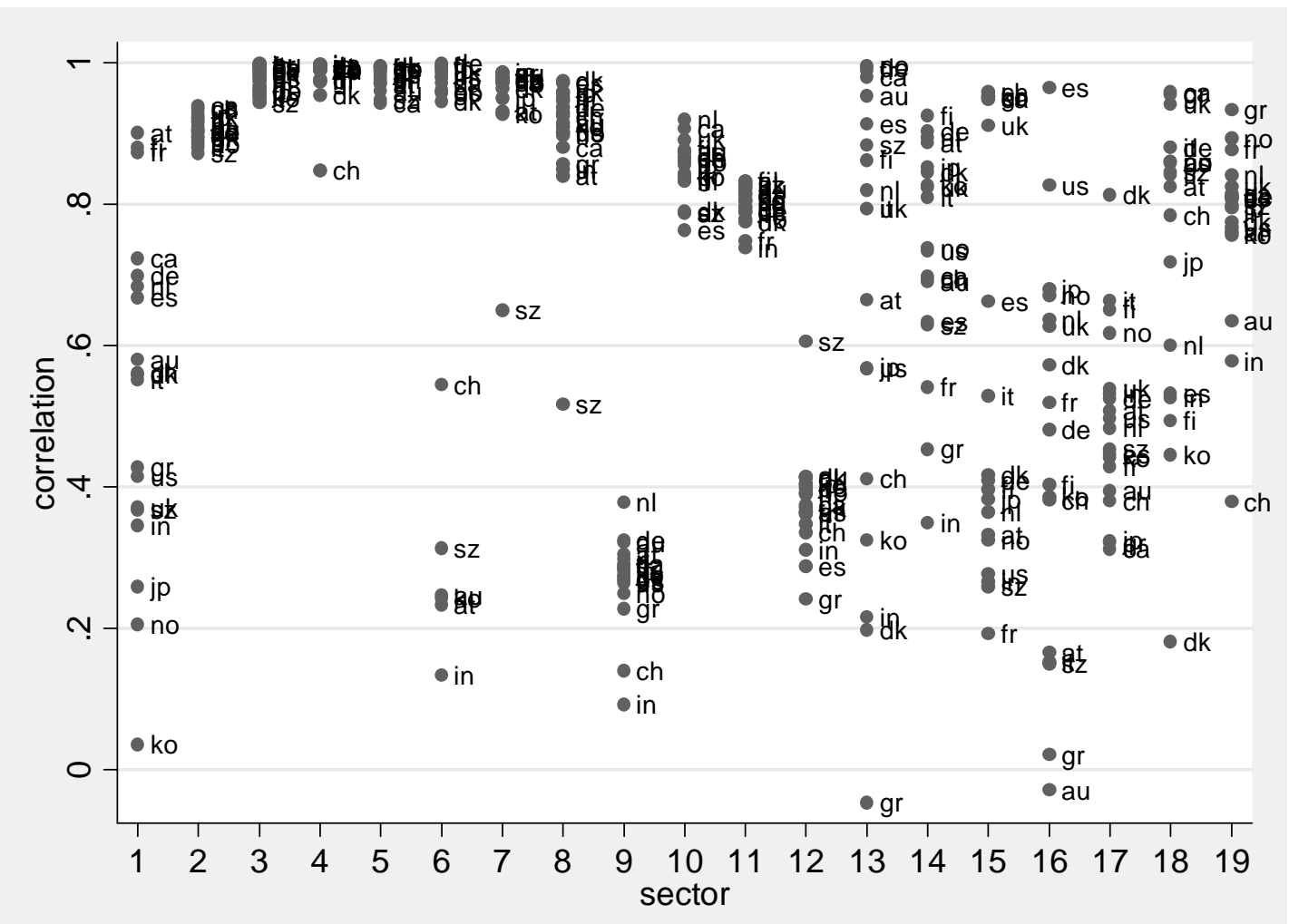

Note: Sectors' codes are given in Table 2

In Table 2 we additionally provide the correlation between the foreign share of output in a sector and the share of locally sourced relative to total inputs by foreign multinationals, 
i.e., the correlation of the standard proxy of HORIZONTAL as in (1) relative to $M_{n t}^{D} / M_{n t}$. As can be seen, there is a wide range of correlation across sectors with no clear detectable pattern. We also calculated the average $M_{n t}^{D} / M_{n t}$ by nationality, reported in Column 2 of Table 1. There is a large variation across country of origin. While this could be due to the different sectoral allocation of production by nationality, further investigation did not provide much evidence in support of this. For example, US plants sourced on average 27 per cent of their inputs locally, while the equivalent figures for Chinese multinationals was over double this.

Finally, Table 3 provides the raw correlations of the various measures of backward spillovers. It is notable that the correlations between the different measures are less than perfect, even though the correlation is positive and statistically significant in almost all cases. An exception is the correlation between the standard backward and the alternative measure based on the IO tables excluding imports.

Table 3: Pair-wise correlations of backward spillover variables

\begin{tabular}{|l|l|l|l|l|l|}
\hline & $\begin{array}{l}\text { Backward_I } \\
\text { O }\end{array}$ & $\begin{array}{l}\text { Backward_N } \\
\text { IMP }\end{array}$ & $\begin{array}{l}\text { Backward_H } \\
\text { OME }\end{array}$ & $\begin{array}{l}\text { Alternative_I } \\
\text { O }\end{array}$ & $\begin{array}{l}\text { Alternative_ } \\
\text { NIMP }\end{array}$ \\
\hline Backward_NIMP & 0.0223 & & & & \\
\hline & 0.0000 & & & & \\
\hline Backward_HOME & 0.4393 & 0.5722 & & & \\
\hline & 0.0000 & 0.0000 & & & \\
\hline Alternative_IO & 0.8488 & 0.0743 & 0.4263 & & \\
\hline & 0.0000 & 0.0000 & 0.0000 & & \\
\hline Alternative_NIMP & -0.0563 & 0.9599 & 0.4778 & 0.0180 & 0.0000 \\
\hline & 0.0000 & 0.0000 & 0.0000 & 0.4798 & 0.4719 \\
\hline Alternative_HOME & 0.4710 & 0.5669 & 0.9822 & 0.0000 \\
\hline & 0.0000 & 0.0000 & 0.0000 & 0.0000 & 0.000 \\
\hline
\end{tabular}




\section{Specification and estimation results}

With the standard and our alternative measures of backward linkages at hand our next task is to investigate how these may produce differing results in terms of their impact on domestic plant productivity. In this regard, one should note that the early studies of the existence of productivity spillovers generally estimate an augmented Cobb-Douglas production function framework in conjunction with standard OLS techniques. However, using panel data, Aitken and Harrison (1999) demonstrate that not controlling for firm fixed effects is likely to bias any conclusion regarding spillovers arising from FDI, so that now panel data and techniques have become the literature standard. A problem with using simple fixed effects in a productivity type equation is, however, that factor inputs should be considered potentially endogenous in the production function. This is the case because the contemporaneous level of TFP may affect the current choice of variable input factors, in which case inputs would be correlated with the error term (e.g., Levinsohn and Petrin, 2003).

The popular approach to deal with this sort of simultaneity is to implement estimators proposed by Levinsohn and Petrin (2003) or Olley and Pakes (1996), which are derived from a structural model. These can be employed to estimate productivity consistently, and then use the derived proxy within a fixed effects framework to control for firm specific time invariant unobservables. The Levinsohn and Petrin approach was recently implemented by, e.g., Javorcik and Spatareanu (2008) and Keller and Yeaple (2009) in the FDI spillovers literature. We follow these examples and employ a Levinsohn and Petrin (2003) type productivity measure controlling for plant specific fixed effects. ${ }^{11}$ Thus our benchmark specification for

\footnotetext{
${ }^{11}$ We implement their methodology, using plant level energy consumption as proxy and then generate total factor productivity as the residual from that regression. We do not use the Olley and Pakes approach for two reasons. Firstly, the approach has been criticised for the use of lumpy investment data as proxy for the unobserved productivity shock (Levinsohn and Petrin, 2003). Secondly, we do not have information on actual investment and, hence, are unable to implement this approach empirically.
} 
measuring spillovers arising from foreign direct investment and potentially affecting domestic plants’ productivity levels is:

$\ln L P_{i t}=\beta_{0}+\beta_{1}$HORIZONTAL $_{j t}+\beta_{2}$ FORWARD $_{j t}+\beta_{3} B A C K W A R D_{j t}+d_{t}+\mu_{i}+\varepsilon_{i t}$

where $L P$ is the Levinsohn and Petrin (2003) measure calculated using only data for domestic firms, $d_{t}$ is a full set of time dummies, $\mu_{i}$ is a plant specific time invariant error term and $\varepsilon_{i t}$ is the remaining white noise error term. ${ }^{12}$ Both the constant and the $\mu_{i}$ are then purged from (8) by implementing a fixed effects estimator. Below we also use an alternative approach, estimating an augmented production function for domestic firms using system GMM, to check the robustness of our results.

Estimation of (8) only allowing for horizontal spillovers is presented in the first column of Table 4 to establish a benchmark. This variable returns a negative but statistically insignificant coefficient, thus suggesting that in Ireland there are no horizontal spillovers. This is analogous to the findings in the literature that have spurned the search for spillovers through backward linkages. We next include the simple standard measure of backward linkages that has been used in the literature in the equation as reported in the second column. The estimation returns a positive and statistically significant (at the ten percent level) coefficient, in line with Javorcik (2004).

How robust is this result to changes in the measurement of the backward spillovers variable that allow relaxing the assumptions spelled out above? In order to investigate this, we start off by using the BACKWARD_NIMP measure, as given in equation (3) and shown in the third column of Table 4. As can be seen, the coefficient on this measure changes relative to the standard one and it turns statistically insignificant. This would thus suggest that relaxing the

\footnotetext{
${ }^{12}$ Note that we do not include a full set of industry dummies as these are captured by the plant specific effect. Industry information refers to the latest year in the data and is, hence, time invariant.
} 
assumption that domestically produced inputs are used in the same proportion as imported ones using an I-O table that distinguishes domestic supplies and imports does make a qualitative difference for judging the importance of spillovers.

In the next regression we employ $B A C K W A R D \_H O M E$ as in equation (4), where we employ Input-Output tables from the multinationals' home countries instead of the host country's I-O table. Now we find that the coefficient is again statistically significant, suggesting that backward linkages indeed produce productivity spillovers to domestic plants.

We subsequently re-estimated (8) but using $A L T E R N A T I V E_{-} I O$, i.e., using an actual measure of local input used by foreign multinationals but proxying from where these inputs are demanded by the host country's I-O table, including those inputs imported. Here we find that the results actually, and arguably implausibly, suggest statistically significant negative spillovers, i.e., that inputs demanded by foreign multinationals from domestic plants reduce domestic plant's productivity. Excluding imports from this the Irish I-O weights, however, renders the coefficient, while still negative, statistically insignificant (ALTERNATIVE_NIMP).

In the last column of Table 4 we employ our final measure of the extent of backward linkages, namely ALTERNATIVE_HOME. This uses information on actual input use of foreign multinationals in Ireland and proxies how the purchase of these is distributed across sectors via the foreign multinationals' origin country I-O weights. As discussed in Section 2, this is our preferred measure for a number of reasons. This variable produces a positive and significant coefficient on the linkages variable, thus suggesting the possible existence of vertical FDI spillovers in Ireland. One may want to note that the coefficient is nearly twice as large as the traditional measure. By contrast, the coefficients on horizontal and forward spillovers are in all cases statistically insignificant. 
Table 4: Estimates of horizontal and backward spillovers

\begin{tabular}{|c|c|c|c|c|c|c|c|}
\hline & (1) & (2) & (3) & (4) & (5) & (6) & (7) \\
\hline \multirow[t]{2}{*}{ horizontal } & -0.097 & 0.930 & 0.577 & 0.843 & 1.179 & 0.408 & 0.779 \\
\hline & $(0.145)$ & $(1.282)$ & (1.267) & (1.273) & (1.298) & (1.274) & (1.271) \\
\hline \multirow[t]{2}{*}{ Forward } & & -1.285 & -0.701 & -0.934 & -1.256 & -0.562 & -0.886 \\
\hline & & $(1.347)$ & (1.306) & $(1.310)$ & (1.331) & $(1.310)$ & (1.309) \\
\hline \multirow[t]{2}{*}{ Backward_IO } & & 0.975 & & & & & \\
\hline & & $(0.563)^{*}$ & & & & & \\
\hline \multirow[t]{2}{*}{ Backward_NIMP } & & & -0.172 & & & & \\
\hline & & & $(0.997)$ & & & & \\
\hline \multirow[t]{2}{*}{ Backward_HOME } & & & & 0.753 & & & \\
\hline & & & & $(0.381)^{* *}$ & & & \\
\hline \multirow[t]{2}{*}{ Alternative_IO } & & & & & -2.119 & & \\
\hline & & & & & $(1.013) * *$ & & \\
\hline \multirow[t]{2}{*}{ Alternative_NIMP } & & & & & & -4.551 & \\
\hline & & & & & & (3.571) & \\
\hline \multirow[t]{2}{*}{ Alternative_HOME } & & & & & & & 1.682 \\
\hline & & & & & & & $(0.926)^{*}$ \\
\hline Observations & 5368 & 5368 & 5368 & 5368 & 5368 & 5368 & 5368 \\
\hline Number of plants & 1038 & 1038 & 1038 & 1038 & 1038 & 1038 & 1038 \\
\hline R-squared & 0.01 & 0.01 & 0.01 & 0.01 & 0.01 & 0.01 & 0.01 \\
\hline
\end{tabular}

Notes: Dependent variable is log TFP estimated using the Levinsohn and Petrin (2003) approach. Estimation with plant fixed effects and full set of time dummies. Constant included

Standard errors in parentheses. * significant at 10\%; ** significant at 5\%; *** significant at $1 \%$

The next issue to be tackled is the potential endogeneity of the spillover variables themselves. If multinationals are prone to locate in high productivity industries, then our finding of a positive relationship between the backward spillover variable and productivity of domestic firm may be biased due to this reverse causality. Assuming that industry productivity does not change much over time, a fixed effects estimator alleviates this problem (as argued by Aitken and Harrison, 1999). However, time variation in industry productivity may be an issue and then a fixed effects estimation would not be sufficient. In order to deal with this problem we, firstly, lag the two spillover variables, reporting the results in Table 5.

The results show that we now only find statistically significant backward spillovers effects in the last column, where we use our preferred measure. Hence, once we try to account for possible endogeneity of the spillover variable, backward spillovers defined using the 
standard measure disappear. Note, also, that the size and statistical significance of the positive backward spillover variable in column (6) is now higher than before.

Table 5: Robustness check: Lagged spillover variables

\begin{tabular}{|c|c|c|c|c|c|c|}
\hline & $(1)$ & $(2)$ & (3) & $(4)$ & (5) & (6) \\
\hline \multirow[t]{2}{*}{ horizontal } & 1.159 & 1.085 & 1.235 & 1.326 & 1.132 & 1.223 \\
\hline & $(1.382)$ & (1.382) & $(1.382)$ & $(1.384)$ & $(1.380)$ & (1.379) \\
\hline \multirow[t]{2}{*}{ Forward } & -1.497 & -1.424 & -1.562 & -1.585 & -1.473 & -1.537 \\
\hline & $(1.437)$ & $(1.438)$ & $(1.437)$ & $(1.436)$ & $(1.436)$ & $(1.435)$ \\
\hline \multirow[t]{2}{*}{ Backward_IO } & -0.016 & & & & & \\
\hline & $(0.652)$ & & & & & \\
\hline \multirow[t]{2}{*}{ Backward_NIMP } & & -0.860 & & & & \\
\hline & & $(0.988)$ & & & & \\
\hline \multirow[t]{2}{*}{ Backward_HOME } & & & 0.399 & & & \\
\hline & & & $(0.381)$ & & & \\
\hline \multirow[t]{2}{*}{ Alternative_IO } & & & & -1.818 & & \\
\hline & & & & $(1.158)$ & & \\
\hline \multirow[t]{2}{*}{ Alternative_NIMP } & & & & & -3.967 & \\
\hline & & & & & $(4.476)$ & \\
\hline \multirow[t]{2}{*}{ Alternative_HOME } & & & & & & 2.246 \\
\hline & & & & & & $(0.975)^{* *}$ \\
\hline Observations & 4434 & 4434 & 4434 & 4434 & 4434 & 4434 \\
\hline Number of plants & 1020 & 1020 & 1020 & 1020 & 1020 & 1020 \\
\hline R-squared & 0.01 & 0.01 & 0.01 & 0.01 & 0.01 & 0.02 \\
\hline
\end{tabular}

Notes: Dependent variable is log TFP estimated using the Levinsohn and Petrin (2003) approach. Estimation with plant fixed effects and full set of time dummies. Constant included. All right-hand-side variables are lagged one period.

Standard errors in parentheses. * significant at $10 \%$; ** significant at $5 \%$; *** significant at $1 \%$

Of course, lagging the variables may not be sufficient if there is, as may be expected, persistence in the variables. Hence, we now turn to an instrumental variables (IV) approach, instrumenting for the spillover variables. In the search for valid instruments we make use of a particular feature of Irish industrial policy, namely, its financial support to foreign multinational companies. Financial incentives in Ireland were not only used to attract multinationals into the economy, but also, at least implicitly, to encourage them to generate 
links with the domestic economy. ${ }^{13}$ We have access to a unique Forfas dataset which provides exhaustive annual plant-level information on all grant payments that have been made to plants in Irish manufacturing. We use this data and calculate the level of government grants given to foreign firms in a four-digit industry, which we use as instrument for the linkage variables. This variable is, thus, likely to be highly correlated with the presence of multinationals in a given sector. As it only includes information on grant payments to foreign owned firms, it is also likely to be uncorrelated with the error term of the equation modelling the productivity of domestic firms, conditional on other regressors. These are the key conditions required by credible instruments. As additional instruments we use twice lagged levels and growth of the spillover variables.

The result of the IV regression controlling for firm fixed effects are reported in Table 6. Firstly note that the instruments used are relevant in all cases as indicated by the first stage Ftest. The Sargan test also indicates that the instruments are valid, with exception of the estimation in column (5). However, in order to have a consistent set of estimations we report these results here, keeping in mind the potential problem of invalid instruments.

Based on these estimations we can conclude that the positive effect of backward linkages is robust in column (6) where we use our preferred measure. There is, however, no evidence for backward spillovers from any of the other backward linkage measures. In particular, compared to Table 4, the coefficient on the standard measure of backward linkages is statistically insignificant, similar to Table 5. Furthermore, there is no evidence for horizontal or forward spillovers in any of the regressions.

\footnotetext{
${ }^{13}$ See Ruane (2001) for a detailed discussion of Irish policy towards linkage generation.
} 
Table 6: Robustness check: Instrumental variables

\begin{tabular}{|c|c|c|c|c|c|c|}
\hline & (1) & (2) & (3) & (4) & (5) & (6) \\
\hline \multirow[t]{2}{*}{ Horizontal } & -0.706 & 1.889 & 1.792 & 1.888 & 2.385 & 1.510 \\
\hline & $(8.374)$ & (4.329) & $(4.400)$ & $(4.464)$ & (4.104) & $(4.421)$ \\
\hline \multirow[t]{2}{*}{ Forward } & -0.006 & -3.379 & -0.940 & 0.464 & -2.412 & \\
\hline & $(5.372)$ & $(5.394)$ & (5.749) & $(5.137)$ & (3.915) & \\
\hline \multirow[t]{2}{*}{ Backward_IO } & 4.274 & & & & & \\
\hline & (6.614) & & & & & \\
\hline \multirow[t]{2}{*}{ Backward_NIMP } & & 0.544 & & & & \\
\hline & & (3.088) & & & & \\
\hline \multirow[t]{2}{*}{ Backward_HOME } & & & 0.797 & & & \\
\hline & & & $(1.351)$ & & & \\
\hline \multirow[t]{2}{*}{ Alternative_IO } & & & & -1.125 & & \\
\hline & & & & $(4.919)$ & & \\
\hline \multirow[t]{2}{*}{ Alternative_NIMP } & & & & & 1.065 & \\
\hline & & & & & $(8.235)$ & \\
\hline \multirow[t]{2}{*}{ Alternative_HOME } & & & & & & 5.301 \\
\hline & & & & & & $(2.707)^{*}$ \\
\hline Observations & 2832 & 2832 & 2832 & 2832 & 2832 & 2832 \\
\hline Number of plants & 670 & 670 & 670 & 670 & 670 & 670 \\
\hline R-squared & 0.03 & 0.01 & 0.01 & 0.01 & 0.01 & 0.01 \\
\hline $\begin{array}{l}\text { F test horizontal (p- } \\
\text { value) }\end{array}$ & 0.000 & 0.000 & 0.000 & 0.000 & 0.000 & 0.000 \\
\hline $\begin{array}{l}\text { F test forward (p- } \\
\text { value) }\end{array}$ & 0.000 & 0.000 & 0.000 & 0.000 & 0.000 & 0.000 \\
\hline $\begin{array}{l}\mathrm{F} \text { test } \\
\text { backward/alternative } \\
\text { (p-value) }\end{array}$ & 0.000 & 0.000 & 0.000 & 0.000 & 0.000 & 0.000 \\
\hline Sargan (p-value) & 0.561 & 0.286 & 0.350 & 0.116 & 0.001 & 0.438 \\
\hline
\end{tabular}

Notes: Dependent variable is log TFP estimated using the Levinsohn and Petrin (2003) approach. Instrumental variables estimation with plant fixed effects and full set of time dummies. Constant included

Standard errors in parentheses. * significant at 10\%; ** significant at 5\%; *** significant at $1 \%$

We now investigate how sensitive our results are to the method of estimating productivity. Thus far we have used the Levinsohn - Petrin approach as this has been used in the literature and thus allows us to compare our results to previous papers. We now use an alternative method of estimating productivity. Rather than proceeding in two steps, i.e., estimating TFP as a residual and then regressing it on the spillover variables we estimate an augmented production function of the form 


$$
\begin{aligned}
& \ln y_{i t}=\alpha_{1} \ln k+\alpha_{2} \ln l+\alpha_{3} \ln m+\beta_{1} \text { HORIZONTAL }_{j t}+\beta_{2} \text { FORWARD }_{j t}+ \\
& \beta_{3} \text { BACKWARD }_{j t}+d_{t}+\mu_{i}+v_{i t}
\end{aligned}
$$

where $\mathrm{y}, \mathrm{k}, \mathrm{l}, \mathrm{m}$ are log output, capital, labour and materials, respectively. As pointed out above, estimating this model using OLS would be biased due to simultaneity of input choices. We therefore treat the factor inputs, as well as the spillover variables as endogeneous and estimate the model using a system GMM estimator, using lagged levels and differences of the variables as instruments.

\begin{tabular}{|c|c|c|c|c|c|c|}
\hline & $(1)$ & $(2)$ & (3) & (4) & (5) & (6) \\
\hline \multirow[t]{2}{*}{$\ln (\mathrm{k})$} & 0.052 & 0.059 & 0.054 & 0.065 & 0.064 & 0.068 \\
\hline & $(0.011)^{* * *}$ & $(0.012)^{* * *}$ & $(0.011)^{* * *}$ & $(0.011)^{* * *}$ & $(0.008) * * *$ & $(0.008)^{* * *}$ \\
\hline \multirow[t]{2}{*}{$\ln (1)$} & 0.309 & 0.325 & 0.316 & 0.303 & 0.318 & 0.300 \\
\hline & $(0.027)^{* * *}$ & $(0.027)^{* * *}$ & $(0.028)^{* * *}$ & $(0.027)^{* * *}$ & $(0.022) * * *$ & $(0.020)^{* * *}$ \\
\hline \multirow[t]{2}{*}{$\ln (\mathrm{m})$} & 0.617 & 0.604 & 0.615 & 0.609 & 0.605 & 0.601 \\
\hline & $(0.018)^{* * *}$ & $(0.019)^{* * *}$ & $(0.019)^{* * *}$ & $(0.019)^{* * *}$ & $(0.015) * * *$ & $(0.014)^{* * *}$ \\
\hline \multirow[t]{2}{*}{ horizontal } & 0.892 & 0.264 & 0.632 & 0.309 & 0.751 & 0.742 \\
\hline & $(0.469)^{*}$ & $(0.480)$ & $(0.495)$ & $(0.485)$ & (0.399)* & $(0.397)^{*}$ \\
\hline \multirow[t]{2}{*}{ forward } & -0.977 & -0.292 & -0.663 & -0.457 & -0.873 & -0.790 \\
\hline & $(0.505)^{*}$ & $(0.491)$ & $(0.505)$ & $(0.499)$ & $(0.408)^{* *}$ & $(0.409) *$ \\
\hline \multirow[t]{2}{*}{ Backward_IO } & 0.132 & & & & & \\
\hline & $(0.234)$ & & & & & \\
\hline \multirow[t]{2}{*}{ Backward_NIMP } & & -0.286 & & & & \\
\hline & & $(0.247)$ & & & & \\
\hline \multirow[t]{2}{*}{ Backward_HOME } & & & 0.153 & & & \\
\hline & & & $(0.138)$ & & & \\
\hline \multirow[t]{2}{*}{ Alternative_IO } & & & & 0.618 & & \\
\hline & & & & $(0.403)$ & & \\
\hline \multirow[t]{2}{*}{ Alternative_NIMP } & & & & & -1.910 & \\
\hline & & & & & $(1.010)^{*}$ & \\
\hline \multirow[t]{2}{*}{ Alternative_HOME } & & & & & & 1.273 \\
\hline & & & & & & $(0.465)^{* * *}$ \\
\hline Observations & 5364 & 5364 & 5364 & 5364 & 5364 & 5364 \\
\hline Number of plants & 1037 & 1037 & 1037 & 1037 & 1037 & 1037 \\
\hline Hansen J (p-value) & 0.259 & 0.070 & 0.185 & 0.124 & 0.067 & 0.201 \\
\hline
\end{tabular}

Table 7: Spillovers in augmented production function using GMM

Notes: Dependent variable is log output. Estimation with system GMM estimator including full sets of industry and time dummies. Constant included

Standard errors in parentheses. * significant at $10 \%$; ** significant at 5\%; *** significant at $1 \%$ 
The results of these estimations are reported in Table 7. This shows the robustness of our results thus far. We fail to find statistically significant backward spillover effects using the standard measure, but find positive spillovers when using the alternative measure we propose.

We discuss in Section 2 why we put forward our alternative measure of backward linkages, using the home country input-output table, as preferred measure. In order to support these arguments further, we, as a final robustness check, randomly assign IO tables to foreign firms from a given country. ${ }^{14}$ If we get the same results based on these hypothetical distributions of IO coefficients, then we should conclude that the positive results we get on the Alternative_HOME measure is just generated by chance. If, however, the results differ, then this suggests that our approach provides useful information on the importance of backward linkages.

In order to check for this, we conduct a Monte Carlo experiment where we assign a randomly chosen IO table to a firm nationality. We then estimate the empirical model using FE, IV and GMM estimators. We repeat this experiment 500 times. Table 8 reports the average coefficients and standard errors obtained from these regressions with the "randomized" Alternative_HOME measure. The coefficients are statistically insignificant in all three estimation approaches. Hence, using a random assignment of the IO tables to firm nationalities actually produces the same statistically insignificant result as using the standard backward linkages measure using the host country IO table. By contrast, our result of positive backward spillovers using the home country IO table for foreign firms produces a result that does not appear to be generated "by chance”.

\footnotetext{
14 This is somewhat akin to Keller (1998) who randomly assigned import shares as weights to R\&D stocks in order to measure trade-related R\&D spillovers.
} 


\section{Table 8: Randomization of the IO table}

\begin{tabular}{|l|l|}
\hline & $(1)$ \\
\hline & Alternative_HOME \\
\hline FE estimator & 0.003 \\
\hline & $(0.155)$ \\
\hline IV estimator & 0.011 \\
\hline & $(1.658)$ \\
\hline GMM estimator & -0.011 \\
\hline & $(0.058)$ \\
\hline
\end{tabular}

Notes: Table reports average coefficient and standard errors on Alternative_HOME from regression models as in Table 2, 4 and 5. The IO tables are randomly assigned. Estimations are based on 500 replications.

* significant at $10 \%$; ** significant at $5 \%$; *** significant at $1 \%$

Taking the results thus far in conjunction with each other, one can now draw a general picture about how and whether assumptions A1, A2, and A3 underlying the standard measure are likely to affect results in estimating spillovers due to backward linkages. In particular it becomes obvious that using the host country's I-O tables, whether including imported inputs or not, may fail to capture vertical spillovers, once potential endogeneity of the spillovers variables is corrected for. More precisely, assuming that foreign multinational input sourcing behaviour is similar to that of their domestic counterparts, and hence that one can simply use the host country's I-O tables which includes inputs usage by both groups, may be inappropriate for the task at hand. Rather multinationals are more likely to source inputs as they do at home. One can also conclude that proxying the intensity of input demand by foreign multinationals is important. In terms of our terminology employed in Section 2, it appears that A2 and A3 are particularly critical assumptions in determining whether backward spillovers are found.

Having established the robustness of our result we now move from statistical to economic significance. One point to note is that the coefficient on backward linkages has increased in size from around 1.6 in the regression in Columns (7) of Table 4 - which assume the variable in contemporaneous levels to be exogenous - to 2.2 in Column (6) of Table 5, about 5.3 in the estimation using instrumental variables in Columnn (6) of Table 6, and 1.3 in 
the final GMM estimation in Table 7 (column 6). These results imply that increasing the backward linkage measure by one percentage point leads to an improvement in TFP by between 1 to 5 percent. To set this in context, the mean of the backward linkage measure is 0.043, i.e., 4.3 percent. Mean TFP is 2.81. The standard deviation around the mean of the backward linkage measure is 0.0369 which can be decomposed into a between (i.e. across plants) standard deviation of 0.0367 and a within (i.e., in the time series variation) component of 0.0054 . Hence, increasing the backward linkage measure by 1 percentage point is roughly equal to an increase by two standard deviations in the time series dimension; i.e., a very substantial increase. This would, on average, increase TFP by between 0.03 to 0.15 , i.e., from 2.81 to between 2.84 to 2.96 .

\section{Conclusions}

This paper takes as a starting point the recent literature on spillovers to domestic firms from backward linkages of multinationals, which has in a number of cases provided evidence of such positive effects. We make explicit the assumptions used to calculate such measures of backward spillovers and argue that these are unlikely to hold in practice. These assumptions implicitly consider that (i) multinationals use domestically produced inputs in the same proportion as imported inputs, (ii) multinationals have the same input sourcing behaviour as domestic firms, irrespective of their country of origin, and (iii) the demand for locally produced inputs by multinationals is proportional to their share of locally produced output. We then provide alternative measures that relax these.

Our empirical analysis shows that results change greatly depending on the measure of backward linkages used and thus on their implicit assumption regarding (i)-(iii). In particular, in our case we do not find robust evidence of spillovers through backward linkages when using 
the standard measure used in the literature. However, when we use our preferred measure which relaxes the arguably unrealistic assumptions we find statistically significantly positive effects. This result is robust to different specifications, in particular to controlling for potential endogeneity of the backward spillover variable. By contrast, the positive effect found initially on the standard measure used in the literature is not robust to controlling for endogeneity.

Our results lead us to a few general conclusions. Firstly, it seems that whether one assumes that foreign multinationals have input sourcing behavior identical to that of domestic firms is crucial in terms of finding backward linkages spillovers. Given that this assumption goes against the very premises underlying the search for spillovers arising from FDI, namely that foreign multinationals are different to their domestic counterparts in production organization mode, it is likely that results for other studies might also change once proxies of backward linkages relaxing this assumption are used. After all, in any host country there are multinationals from different home countries with arguably different technologies and input sourcing behaviour. Our results suggest that these differences impinge on potential backward spillovers arising from FDI.

Of course, it is difficult to infer that our finding for the case of Ireland is a general finding. Hence, it is not a priori clear that other studies suffer from the same problem. By the same token, however, it is also not a priori to be taken that other studies do not have the same problem, without doing a careful analysis with alternative measures. Hence, our suggestion is that conclusions from such studies should be treated with caution. Ideally, analyses should make use of measures of backward spillovers that do not rely on the assumption of identical input sourcing behaviour among multinationals, to the extent, of course, that such data is available to the researcher. 


\section{References}

Aitken, Brian J., and Ann E. Harrison. 1999. "Do Domestic Firms Benefit from Direct Foreign Investment? Evidence from Venezuela.” American Economic Review 89(3): 605-18.

Alfaro, L. and A. Charlton (2009), "Intra-industry foreign direct investment", American Economic Review, forthcoming.

Amiti, M. and S.J. Wei (2009), "Service offshoring and productivity: Evidence from the US”, The World Economy, 32, 203-220

Barry, F. and J. Bradley (1997), FDI and trade: The Irish host-country experience, Economic Journal, 107, pp. 1798-1811.

Belderbos, R., G. Capannelli and K.Fukao (2001), "Backward Vertical Linkages of Foreign Manufacturing Affiliates: Evidence from Japanese Multinationals", World Development 29(1): 189-208

Blalock, G. and P.J. Gertler (2008), "Welfare gains from foreign direct investment through technology transfer to local suppliers”, Journal of International Economics, 74, 402-421.

Buckley, P. and R. D. Pearce, "Overseas Production and Exporting by the World's Largest Enterprises: A Study in Sourcing Policy", Journal of International Business Studies 10 (1): 920

Caves, Richard E. 1974. "Multinational Firms, Competition, and Productivity in Host-Country Markets.” Economica 41(162): 176-93.

Girma, S. and Wakelin, K. (2009), Local Productivity Spillovers from Foreign Direct Investment in the U.K. Electronics Industry, Regional Science and Urban Economics, forthcoming

Gorodnichenko, Y., J. Svejnar and K. Terrell (2007), When does FDI have positive spillovers? Evidence from 17 Emerging Market Economies, IZA Discussion Paper 3079

Görg, H., A. Hanley and E. Strobl (2008), "Productivity effects of international outsourcing: Evidence from plant level data", Canadian Journal of Economics, 41, 670-688.

Görg, H. and E. Strobl (2001), "Multinational companies and productivity spillovers: A metaanalysis" Economic Journal, Vol. 111(475), F723-F739

Head, K. and T. Mayer, (2004), "Market Potential and the Location of Japanese Firms in the European Union", Review of Economics and Statistics 86(4), 959-972.

Hirschman, A. 1958. The Strategy of Economic Development. New Haven: Yale University Press. 
Javorcik, B.S. (2004): “Does Foreign Direct Investment Increase the Productivity of Domestic Firms? In Search of Spillovers through Backward Linkages", American Economic Review, Vol. 94, pp. 605-627.

Javorcik, B.S. and M. Spatareanu (2008), “To Share or Not To Share: Does Local Participation Matter for Spillovers from Foreign Direct Investment?”, Journal of Development Economics, Vol. 85.

Keller, W. (1998), “Are international R\&D spillovers trade-related? Analyzing spillovers among randomly matched trade partners”, European Economics Review 42, 1469-1481.

Keller, W. (2004), “International Technology Diffusion”, Journal of Economic Literature 42: $752-782$.

Keller, W. and S. Yeaple (2009), “Multinational Enterprises, International Trade, and Technology Diffusion: A Firm-level Analysis of the Productivity Effects of Foreign Competition in the United States", Review of Economics and Statistics, forthcoming.

Levinsohn, J. and A. Petrin (2003), Estimating production functions using inputs to control for observables, Review of Economic Studies, 70, pp. 317-341.

Markusen, J.R. (2002), Multinational Firms and the Theory of International Trade, MIT Press.

Markusen, J.R. and Venables, A.J., 1999. Foreign direct investment as a catalyst for industrial development. European Economic Review 43, pp. 335-356.

Moran, Theodore. 2001. Parental Supervision: The New Paradigm for Foreign Direct Investment and Development. Washington, D.C.: Institute for International Economics

Moran, Theodore, 2005, "How does FDI affect host country development? Using industry case studies to make reliable generalizations”, in Moran, T., E. Graham and M. Blomström (eds.), Does Foreign Direct Investment Promote Development?, Washington DC: Institute for International Economics, pp. 281-314.

Munch, J.R. and J.R. Skagsten (2009), Specialization, outsourcing and wages, Review of World Economics, 145, pp. 57-73.

Olley, S. and A. Pakes, (1996), "The dynamics of productivity in the telecommunications equipment industry, Econometrica 64: 1263-98.

Rodríguez-Claré, Andres. 1996. "Multinationals, Linkages, and Economic Development.” American Economic Review 86(4): 852-73.

Ruane, F, 2001, Reflections on linkage policy in Irish manufacturing - policy chasing a moving target?, mimeo (available at www.unece.org/ead/misc/ffd2001/ruane.doc, accessed 0307-08) 